\title{
Proposal Integrated Curriculum of Islamic Elementary School in Islamic Education Philosophy Frame
}

\author{
Andi Thahir ${ }^{1}$, Tin Amalia Fitri ${ }^{2}$, Rahmahwaty ${ }^{3}$ \\ \{andithahir@radenintan.ac.id ${ }^{1}$, tinamaliafitri@ radenintan.ac.id ${ }^{2}$,rahmahwaty@ radenintan.ac.id $\left.^{3}\right\}$ \\ 1,2,3 Universitas Islam Negeri Raden Intan Lampung, Jl. Letnal Kolonel Endro Suratmin, Sukarame, \\ Bandar Lampung, Indonesia
}

\begin{abstract}
Integrated Islamic Elementary School has experienced a very encouraging development, as a school that has an aim to direct education into Islamic but still under the rules of the Ministry of Education of the Republic of Indonesia, Integrated Islamic Elementary Schools use general education curriculum and include Islamic education curriculum. It is very important to know whether the curriculum is applied in accordance with the framework of Islamic education or not. The related problems are how the philosophy of education in Islamic is, how the education curriculum in Islamic is, how the education curriculum of the Islamic primary school integrated is, and how it fits to. The research design uses a literature study, which examines the thoughts of Islamic education in this matter, especially Imam al-Ghazali and Ibnu Khaldun, this design is used to answer the first to third problem formulations, while the fourth problem formulation uses a qualitative approach to interview methods and FGD techniques. The results of this study indicate that the objectives and methods that has been applied in the Integrated Islamic elementary school in Bandar Lampung City are in accordance with the objectives and methods of Islamic education, but there are some weaknesses in the integration of general science and Islamic religion applied in the curriculum of Integrated Islamic Elementary School education, that is the assortment subjects so they repeat themselves for a long time, like in Islamic Education subject, there is a discussion about Tauhid, memorization of Al-Quran, Tajwid, Islamic history, while this subject is a branch of knowledge in Islamic, moreover it is a branch of science itself. A study is needed to improve some subjects that are in accordance with the philosophy framework of Islamic education.
\end{abstract}

Keywords: Philosophy of Islamic Education, Integrated Islamic Elementary School.

\section{Introduction}

\subsection{Background of the Problem}

Various problems faced by humans today are believed to be one of them caused by the disorientation of science. The disorientation in question is that science based on positivistic philosophy has given birth to materialist individuals, that is, individuals who believe in matter as their ultimate goal. Physics, mathematics, chemistry, and various other sciences in addition to producing advanced technology that helps human life, also gives birth to the destruction of nature and the destruction of human civilization.[1]

Human civilization at this time is believed to develop on the foundation of the positivism of thought, even the human reasoning power and the order of values in the individual at this time develops dominantly from the positivism of thought. Positivism literally means several meanings: The First, a positive term means conclusion, a summary of actions taken from 
divine and human institutions as distinguished from naturally, certainly, and eternally. For example, a positive law is distinguished from natural law and divine law. The Second, a positive term implies practical, appropriate, useful and certain. The Third, some certain ways of thinking used to recognize objects in a form of ways of thinking that prioritize experience, data and facts (practical-empirical) rather than the formulation of theory and speculation. Positive refers to scientific thinking based on experiences.[2]

Positivism is a philosophical flow that approaches and understands objects based on empirical data sets and mathematical calculations. From the point of philosophy, positivism is a way of thinking that assumes the main and the first pillar of scientific knowledge is the experience and observation of objects that are perceived and experienced as definite data or facts. The method of positivism implies a work method that begins from an empirical observation of phenomenon, object, fact, or reality. The purpose of such observations is to find linkages and working laws and to arrange objects so it can be made a logic prediction.

Positivism becomes a dominant flow of thought that is closely related to the result of achieved progress by non-philosophical sciences such as physics, mathematics, biology, chemistry, astronomy, and technical engineering. The principles and natural laws that control all things into the machine. The diversion of natural principles and laws also has produced products of super-sophisticated scientific discoveries and technical engineering such as, electricity, cellphones, internet systems, DNA discoveries, etc. so that the findings have become an absolute justification for the validity and superiority of positive science compared to other disciplines.[2]

But behind its dominating superiority and usefulness for human life, positivism is also considered as a root of problem of one-dimensional human-being's birth because human civilization that is guarded by positivism changes reason or logos into technology. The relationship between technological reason is the cause of the destruction of values order and human orientation, Herbert Mercuse observantly found a critical point, namely the ambivalence of technology, which is the dimwardness of technology feature. On the one hand technology brings progress, simplicity, freedom, excitement, but on the other hand it also brings complexity, distress, deterioration, deterrence, and destruction because technology also has an impact and implication for reality and the psychic world. This explanation is that the technological conquest of nature which then has an impact on the abundance of material, luxury, comfort, and simplicity of life. It is an intermediary for the conquest of these technical devices on human life, at this time human must match and give himself up to be controlled and directed by machines that engineered by human, himself. As Lewis Mumford said that in a technological society there is a shift in the position of individual, that is, machines has become factors and human beings have become factum.[2]

The flow of positivism thought also has entered to the systematization of education, because the development of human civilization is the result of education until now. In order to clarify positivism as a school of thought that forms the basis of education, it can be explored through the study of thought by Imanuel Kant who has removed the gap between reason and reality, by returning to the subject of thinkers. So, focus and search for rational knowledge must be centered on the subject of thinking, recognizing, pondering, and investigatingo of reality. Originating from the analysis on the basis of thought process in the subject of thinking, knowledge can be divided into external and internal scope, so that ontological studies are replaced with epistemological analysis.[2]

Thus, science keeps continuing to develop and produce discoveries about the causes, principles, and laws that underlie and regulate phenomenon. It does not only stop as information or material knowledge that is frozen in theoretical formulas or books, but these 
principles and laws must continue to be studied and developed, tested and then transferred into machine and sophisticated technology. Furthermore, the use of science and technology in the industrial world is oriented in product and profit rather than the fulfillment of life naturally and the realization of individual potential, this extends to all aspects of human life. So humans are only valuable as far as producing or having the energy to work. The role and function of humans are equal with the role and function of machine, which is the cause of human decline due to a switchover in orientation to competitiveness under the interests of markets and capital, glorification of power, abundance of assets, and worship of the reality and individual status in a society. This condition; which is education, science give result materialistic human.

Concerning about the condition of education that is surrounded by positivistic thought has increased the awareness of many parties regarding the strategic function of education. in the last decade, the emergence of integrated Islamic schools, from the level of early childhood education to tertiary education. Integrated Islamic school is a school that combines general lessons based on the national curriculum with Islamic religious lessons. This school has quite a lot of load, so the study hours is longer. So this school is often referred to as 'full day school'. So in this integrated Islamic school, students besides learning general subjects such as mathematics, Indonesian, natural sciences, social studies and others also studying religion. The lessons that are related to this religion include recitation, memorization of prayers, memorization of hadith, obligatory congregational prayers and sunnah (such as Dhuha), Islamic history, fiqh and others. Including the formation of Islamic morals, behavior and habits. In the world of higher education there is a movement to change religious tertiary institutions such as institutes or colleges into universities, this change is motivated by the spirit so that graduates of religious education can be used in the world of work based on markets, capital, and technology.[3][4]

The changing must be criticized, so that the spirit that underlies the changing does not make the existance of civilization damaged and destroyed by materialism-oriented individuals, namely the religious justification of the destruction and decline of civilization, dehumanization, and disorientation of individual values. The criticism step will be carried out through an integrated Islamic school education curriculum review especially the Integrated Islamic elementary school using the flow of thought approach, and the foundation of educational philosophy according to how many Islamic thinkers (Imam Al-Ghazali, Ibnu Khaldun). The review of the integrated Islamic elementary school education curriculum is based on the function of the curriculum as a set of plans and arrangements regarding educational goals. Meanwhile, the integrated Islamic elementary school, initially moved to change the awareness of the current state of the world, especially in Indonesia. Subjectively, the integrated Islamic elementary school that is the object of study is a school located in Bandar Lampung City, Lampung Province.

\subsection{Formulation of the problem} as follows:

Based on the background of the problem, the formulations of this research problem are

1. What is the basic framework of the philosophy of education in Islamic according to Islamic experts Imam Al-Ghazali and Ibn Khaldun?

2. How is the curriculum framework in accordance with the foundation of the philosophy of education?

3. What educational philosophy underlies the curriculum of Islamic elementary school education in Bandar Lampung City? 
4. How far is the suitability of the integrated Islamic elementary school education curriculum in Bandar Lampung City against the basic framework of the philosophy of Islamic education?

\section{Research Methods}

\subsection{Object of Study}

This research will use literature study, content analysis, and qualitative method.[5] The literature study method is needed to get the formulation of an educational curriculum from synthesizing result that has been done by the promotor of positivism, and Islamic Expert Imam Al-Ghazali. The research then will continue with a review of the curriculum used by integrated Islamic elementary schools, at this stage content analysis method will be used to obtain a comparison and measurement of inclination in the use of integrated Islamic elementary school curricullum. In order to achieve valid comparisons and measurements of curriculum trends used by integrated Islamic elementary schools, the study will be continued to a qualitative research, specifically by doing observation or students' observation to see the result of applying the curriculum used by integrated Islamic elementary schools.

\subsection{Research Data Sources}

Research sources that will be used are:

1. Documentation

The intended documentation is in the form of books related to positivistic thinking methods related to curriculum and educational methods, books by Islamic Experts such as Imam Al-Ghazali, and Ibn Khaldun that will explain about problems related to philosophical foundation or thinking methods related to curriculum and education method.

2. Curriculum Blueprint

The intended curriculum blueprint is that owned and used by an Islamic elementary school in Bandar Lampung, as well as the national basic education curriculum.

3. Interview Results

The interview will be used to complete the analysis of background related to the use of the curriculum, and to gain an understanding of the reasons in using an integrated Islamic elementary school curriculum.

4. Observation Results

An Observation is intended to obtain validity of the semantic data measurements that have been made previously.

\subsection{Data Analysis}

Data analysis include temporary conclusions, and then conclusions as a whole, then explained with a descriptive explanation. The data obtained through the results of interviews with the Focus Group Discussion techniques are interpreted by looking at their suitability with educational goals, educational materials, educational methods, educational evaluations that have been extracted from some literature of Islamic thinkers.[6][7] 


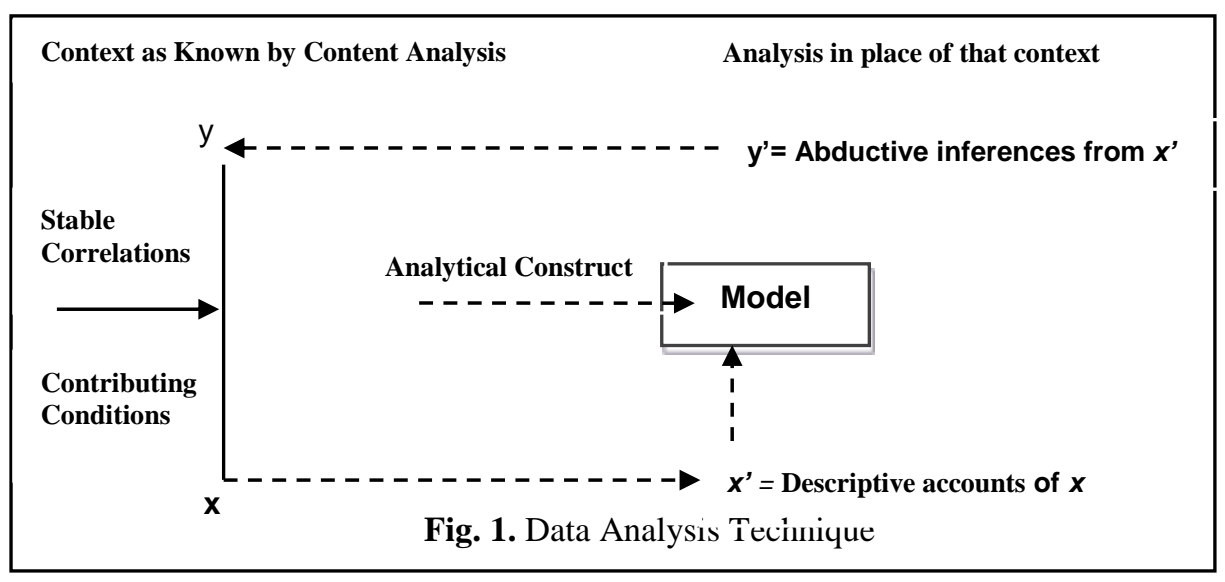

\section{Discussion}

An overview of the integrated Islamic elementary school curriculum is carried out by looking at the learning objectives, subjects, and methods applied in the Integrated Islamic Elementary School of Muhammadiyah and Permata Bunda Bandar Lampung. It has been explained above that the goal is to create humans or students who are salimul aqidah that have strong and clear faith for Allah SWT, shahihull worship means always does worship that Allah SWT has already commanded because the way to achieve salimull aqidah is shahihull worship, salimull Aqeedah can not be achieved without becoming a shahihull of worship first, firm "matinul khuluq or Akhlak" because shahihull aqidah is achieved by way of matinul khuluq namely the attitude and behavior of the servant to his creator, mustaqqatul fikri or intellectual that thinks to become shahihull of worship, salimulul Aqeedah. Matinul khuluq means science and reason is the source of knowledge. Then, some characters that must be in a moslem to be of salimul aqidah namely mujahadatul linafsihi or struggle against lust, harishun ala waqtihi or being good at arranging time, munazhzhamun fi syuunihi or being regularly in matters, qodirun ala kasbi or having an ability or effort of his own, nafi'un liqhoirihi or useful to others.

The purpose of Islamic Education abstracted from the thoughts of Imam al-Ghazali, Ibn Khaldun, and other experts contained in this research literature is the same as the goals set by the Integrated Islamic Elementary School, because basically those goals are abstracted from these Islamic experts, whose thoughts are sourced from the hadiths, sunnah, and verses of the Qur'an. The purpose of education is to build up aqidah, create the character of students in accordance with Islamic teachings. There are 10 characters that have been mentioned. Teaching science is as a way for true and pure aqidah, besides, as a way to achieve the perfection of students in the world because of the world's journey is the provision of life in the hereafter. So in term of the Basic base Education, the Integrated Islamic Elementary School formulates the synergy objectives in line. [8]

The characters that are going to be achieved as a result of the process of education or learning in integrated Islamic elementary schools shows the objectives of integrated Islamic education including integrated Islamic elementary schools. Tehse are subsequently achieved 
with the material and methods applied by the Integrated Islamic Elementary School, namely whether the material taught by teachers are relevant or not to the purpose of learning, and whether the method applied is fit to the learning material or not in order to get the intended goals.. The materials and methods referred to are part of the education curriculum which will then be reviewed or seen in common and their compatibility with the materials and methods that have been described by Imam al-Ghazali and also Ibn Khaldun, and other moslem experts in the literature on this study. The contents in the curriculum at the Integrated Islamic Elementary School are composed of:

1. Attitude: the assessment of accepting and practicing about their own religious. It is like in Islamic elementary school, students are taught to do the dhuha prayer, the midday prayer, and murojaah; which is to memorize the holy verses of the Qur'an. Attitude assessment also consists of evaluating honesty, courtesy, discipline, responsibility, trusting in interacting. One of the evaluation is observed by delivering greeting. The attitude referred to Islamic Education as described by Imam al-Ghazali is building of ahlakul karimah, in this case there is no specific methods for instilling an attitude or behavior in accordance with Islamic teachings. The use of the word attitude should also be replaced by the term 'ahlakul karimah' because'ahlak in Moslem has very clear reference to As-Sunnah, while the term reference of 'attitude' has still very vague indicator.

2. Knowledge: the content of subjects that is taught such as mathematics, Indonesian, Citizenship Education (PKN), Islamic Education (PAI), Physical Sports and Health Education (PJOK), Cultural Arts and craftsmanship (SBDP). These school subjects have got the biggest part teaching in this school. Comparing to the description of Islamic education according to Imam al-Ghazali that the greatest knowledge taught to students as early as possible is building of aqeedah related to the existance of Allah Ta'ala that Allah is the Almighty. The teaching about Allah's deeds "Azza Wa Zalla. Then, the teaching of Aqidah should be the greatest content which is given in regular steps in accordance with the development of the age of the students. Although the content of this aqidah is taught in the PAI (religion subject), but the time duration is very limited, such as at first grade, the children are only taught about the law of faith and the moslem pillars for a year. Then, it is continued with the next classes the subject of aqidah remains about the law of faith and moslem, as described by Ibn Khaldun, the giving of a point of knowledge should not be too long so that students will not know the meaning of the knowledge taught to them. Besides, The material in PAI is mixed for some level of classse. It contains about aqidah, ahlak, tajwid, understanding of the contents of some verses of the Qur'an. Sure, it was a mixed branch knowledge act.

3. Local Content: Local content subjects include Arabic, English, Lampung Language and Computer Information Technology. It is taken from Ibn Khaldun's description that the basic of understanding Qur'an is Arabic. Then, by setting the objectives of Islamic Education Arabic lesson should have a bigger portion of learning and continue to develop in accordance with the development of mastery by students. in addition, the material of Arabic learning can not be separated from learning of Arabic writing as a different content. In this matter Arabic writing material lies within the content of the Islamic Kemuhammadiyahan.

4. Moslem Kemuhammadiyahan: Learning material consists of prayer, tahsin, and tafidz. So it has been seen that the basis for the provision of religious knowledge is not based on the development of the needs of students such as fardhu's commentary 
on the material taught which is delivered by Imam al-Ghazali, the given material is based on the sharing of knowledge itself. through this condition, students remain as an object and the subject is knowledge itself. It is needed to have a review in detail toward the content of the curriculum in the Integrated Islamic Elementary School in order to get the goal. The students have already got because of many subjects accepted by them, this condition actually should be avoided in order to guide and build up good attitude (akhlak) within the good method's applied.

The weaknesses in the Integrated Islamic Elementary School curriculum is the setting of full appliction set by the government, which is the same as general education. The difference is in some local contents such as Arabic and Islamic content, namely memorization of AlQur'an letters that are adjusted with the level of age and memorization of prayers and hadiths. So, the contents of inserting aqidah and building of ahlak has limited portion. The method applied is still unclear as to its accuracy. It is needed a depth-research in order to achieve the correct and appropriate materials and methods.

\section{Conclusions}

The conclusion of this study is as follows:

1. The basic framework of the philosophy of education in moslem according to Islamic Expert, Imam al-Ghazali is related to the purpose of education in Moslem, that education is a process of learning and teaching that aims to seek the pleasure of Allah SWT. Education aims to guide people to the way to the hereafter. In this case, the attainment of the hereafter is the achievement of the world because the world is a way to the hereafter. Therefore, in term of science in Moslem according to Imam alGhazali broadly divided into world knowledge and the hereafter. The afterlife is a a knowlege derived from the Qur'an and Sunnah that can be achieved with the perfection of mind and heart, while world knowlege is a knowledge to achieve the perfection of the world so that it includes fiqh, and other knowledges developed based on the development of one's knowledge.It consists of supporting knowledges related to the understanding and mind-exploration that is basically based on distilling water in rose flower, in other words, the knowledge toward Allah SWT is human nature, and has existed since humans were delivered into the earth.[9]

2. The curriculum framework is related to the educational philosophy framework in Islamic. According to Imam al-Ghazali, it has been in some steps in accordance with Fardhatan. It is in accordance with the development of students and the development of their minds, as well as their life needs. The earliest phases in education are building up of aqidah and ahlak because these two things are interrelated, aqidah in children at the beginning of education is basic education carried out by the doctrination method about the attributes of Allah SWT, the manifestations of Allah SWT, and the actions of Allah SWT, these three things are the base of aqidah. The absolute teaching must been done through the example of teachers, parents, and the environment and through learning to manage the state of the heart that is commendable in order to produce good deeds. Building up aqidah and ahlak must be delivered continuously without interruption. The curriculum must be considered not to mix the branches of knowledge because it will only create confusion in students, the main branch of knowledge must be known as the basic of knowledge given to students. The first, the starting point of learning must be adjusted to the capacity of 
students in terms of knowledge and thinking ability. Methods of violence must be avoided, because education is more successful given in an atmosphere of tenderness and approach to the students.

3. The Philosophy of education which underlies the Integrated Islamic Elementary School is Islamic education, the curriculum framework applied is the framework of educational philosophy similar to the findings found from the thoughts of Islamic Experts especially Imam al-Ghazali and Inbu Khaldun.

4. The Weaknesses in the suitability of the education curriculum in the Integrated Islamic elementary school in Bandar Lampung City are in the method of building up aqidah and ahlak to students.

\section{References}

[1] I. Khaldun, Mukaddimah, Terjemahan. Jakarta: Pustaka Al-Kautsar, 2001.

[2] H. Mercuse, Perang Melawan Kapitalisme Global, Terjemahan. Jakarta: Gramedia, 2000.

[3] A. Tafsir, Ilmu Pendidikan dalam Perspektif Islam. Bandung: Remaja Rosdakarya, 2005.

[4] Achmadi, Islamic Education Ideology: Humanism Theories Paradigm. Yogyakarta: Pustaka, 2005.

[5] L. J. Moleong, Metodologi Penelitian Kualitatif. Bandung: Remaja Rosdakarya, 2004.

[6] Sudarto, Metodologi Penelitian Filsafat. Jakarta: Raja Grafindo Persada, 1997.

[7] B. Salam, Etika Individual: Pola Dasar Filsafat Moral. Jakarta: Rineka Cipta, 2000.

[8] I. Al-Ghazali, Ihya Ulumuddin, 1st ed. Semarang: CV.Asy-Syifa, 1990.

[9] Kementerian Agama Republik Indonesia, Syaamil Al-Qur'an Miracle te Refrence Juz 1-30. Sygma Publishing, 2010. 